Vol.15, No.1, 2020, Hal. 77-90

\title{
ISLAM DAN DISKRIMINASI LGBT DAMPAKNYA PADA PENURUNAN EKONOMI
}

\author{
Yusnani' $^{1}$, Welsi Haslina ${ }^{2}$, Magfirah ${ }^{3}$ \\ 1 Jurusan Akuntansi Politeknik Negeri Padang \\ e-mail: yusnani57@gmail.com \\ ${ }^{2}$ Jurusan Akuntansi Politeknik Negeri Padang \\ e-mail:welsih@yahoo.com \\ ${ }^{3}$ Fakultas Ilmu Sosial dan Ilmu Politik Pasca Sarjana Unand Padang \\ e-mail:magfirah616@gmail.com
}

\begin{abstract}
Sexual relations between members of the same sex article 292 of the Indonesian Criminal Code (KUHP) regulates that adults who commit immoral acts of same-sex homosexuals who are not yet adults are threatened with imprisonment for a maximum of five years. Islam regulates both the Qur'an and Al-Hadith in qath'i (firm) and muhkamat (clearly legal provisions) strongly opposed this behavior. Allah calls homosexual acts fashyyah (vicious bandages) accursed. This study applied the concept of the role of the clerics of the Health Service Coordinating Board in the prevention of homosexual HIV / AIDS in the city of Padang, a method for overcoming a combination of qualitative and quantitative approaches resulting in policy recommendations. To describe the analysis of this research used descriptive method of prescriptive synthesis analysis. The government has not yet implemented the Draft Law article 292 The proposal applies a criminal law of five or a maximum of ten years, both adults and children or is punished equally with adultery both whipping law for single whips for married people. The regional economy will rise if the Islamic economy is upheld, investors can advance if they intend to improve the welfare of living together.
\end{abstract}

Keywords: Economic, Discrimination, Islam, LGBT.

\begin{abstract}
Abstrak
Hubungan seksual antara sesama jenis pasal 292 Kitab Undang-Undang Hukum Pidana (KUHP) mengatur orang dewasa yang melakukan perbuatan cabul sesama jenis homoseksual belum dewasa diancam pidana penjara paling lama lima tahun. Islam mengatur dalam Al Qur'an maupun Al-Hadis secara qath'i (tegas) dan muhkamat (jelas ketetapan hukumnya) menentang keras perilaku ini. Allah menyebut perbuatan homoseksual sebagai fashiyah (perbutan keji) terlaknat. Penelitian ini terapan konsep peran serta ulama pemko dinas kesehatan pada penanggulangan HIV/AIDS homoseksual di kota Padang tata cara penanggulangan kombinasi pendekatan kualitatif dan kuantitatif menghasilkan rekomendasi kebijakan. Untuk memaparkan analisis penelitian ini digunakan metode deskriptif analisis sintesis preskriptif. Pemerintah belum menerapkan Rancangan Undang Undang pasal 292 Usulan memberlakukan hukum pidana lima atau maksimal sepuluh tahun, baik dewasa maupun anak-anak atau dihukum sama dengan zina baik hukum dera bagi lajang cambuk bagi yang menikah. Ekonomi daerah akan naik jika ekonomi Islam ditegakkan, investor bisa maju jika berniat meningkatkan kesejahteraan hidup bersama.
\end{abstract}

Keywords: Ekonomi, Diskriminasi, Islam, LGBT

\section{PENDAHULUAN}


Negara Indonesia adalah negara hukum yang berdasarkan Pancasila dengan menjunjung tinggi nilai nilai moral, etika, akhlak mulia, dan kepribadian luhur bangsa, beriman dan bertakwa kepada Tuhan Yang Maha Esa, menghormati kebinekaan dalam kehidupan bermasyarakat, berbangsa dan bernegara, serta melindungi harkat dan martabat setiap warga negara.(Undang- Undang RI Tentang Pornografi dan ITE, 2011:1) [1]

Dalam hukum positif Indonesia, hubungan seksual antar sesama jenis diatur dalam pasal 292 Kitab Undang-Undang Hukum Pidana (KUHP) mengatur bahwa orang dewasa yang melakukan perbuatan cabul dengan orang lain sesama kelamin, yang diketahui dan sepatutnya belum dewasa diancam dengan pidana penjara paling lama lima tahun. (KUHP DAN KUHAP Surat Putusan Mahkamah Konstitusi Nomor 9/PUUV/2007 Tentang Perubahan Pasal 154 dan 155 Dalam KUHP, 2019:102) [2]

Kegiatan seksual memiliki khasiat multi disamping mengikuti kehendak alam yang bersifat naluri, kehendak yang Maha Kuasa juga tanda sebagai pengamal sunnah maupun memenuhi kebutuhan yang memang perlu dilaksanakan. Sebagai naluri dibatasi oleh aturan yang dibolehkan dan dilarang Allah. (Lukman Saksono, 2019:318).

Permasalahan homoseksualitas di Indonesia dianggap tabu bagi masyarakat dan pemerintah karena jarang adanya diskusi publik membahas persoalan seksualiatas dalam bentuk apapun khusususnya tentang homoseksual secara terbuka. Serta penilaian masyarakat pada pandangan agama dianggap sebagai dosa, dari sudut pandang medis dianggap sebagai penyakit, menurut hukum dianggap sebagai penjahat, dan masyarakat menganggap sebagai penyimpangan sosial.

Transgender di Indonesia (LGBT) penyebutannya bervariasi seperti “ waria, banci, bencong, wadam atau bisu. Orientasi seksual mereka dianggap sebagai suatu penyimpangan haram dosa dan terlaknat. Apalagi didukung oleh fatwa Majelis Ulama Indonesia (MUI) tanggal 31 Desember 2014 yang ditanda tangani oleh Prof. Dr. H. Hasanuddin , AF, MA bahwa homoseksual yang merupakan perbuatan hukumnya haram merupakan suatu bentuk kejahatan dan pelakunya dijatuhi hukuman mati. " Ibarat jatuh ketiban tangga" fatwa MUI melengkapi beban seorang LGBT yang terdiskriminasi dari keluarga, masyarakat dan Negara. Agama Islam membawa misi rahmatan lil 'alamien menjadi tidak rahmat (kasih) lagi hanya karena fatwa MUI yang bias gender "ketiga". (Masthuriyah Sa'dan, Proceding, Metro International Conference on Islamic Studies (MICIS, 2016)

Waria dalam kontek psikologis termasuk dalam transeksualisme, yakni seseorang yang secara jasmani jenis kelaminnya jelas dan sempurna, namun secara psikis cenderung menampilkan diri sebagai lawan jenis (Koeswinarno, 2004). Transeksualisme, menurut Carroll (dalam Davidson, Neale dan Kring, 2004) merupakan individu dengan gangguan identitas gender yang umumnya dimulai sejak kecil dimana ia merasa dan meyakini bahwa dirinya adalah jenis kelamin yang berkebalikan dengan keadaannya yang sebenarnya. Perasaan ini terus berlanjut dari kecil hingga dewasa. (Yus Darusman, Wiwin Herwina, 2016:7) 
Seks bukan hanya menyangkut ejakulasi bagi seorang pria. Yang terpenting adalah kerukunan dan kesamaan hati, dan bukan harus setiap waktu, dan bukan pada saat yang lain. Tetapi pada saat kenikmatan jasmani bergumul kegembiraan yang luar biasa bukan hanya saat orgasme Seoarang pria dapat memiliki kekuatan yang memperoleh kepuasan dalam orgasme dengan wanita yang dicintainya. (Lukman Saksono, 2019:293)

Makna lain seks lebih ditekankan pada keadaan anatomis manusia yang kemudian memberi "identitas" kepada yang bersangkutan. Seseorang yang memiliki anatomi penis disebut laki-laki. Sedangkan orang yang memliki anatomi vagina disebut perempuan. Istilah seks umumnya digunakan untuk merujuk kepada persoalan reproduksi dan aktifitas seksual. Karena penekanannya lebih pada hal-hal yang bersifat anatomis, maka seks kemudian sering dimaknai sempit sebagai hubungan badan antara laki-laki dan perempuan. Naluri seks itu sendiri merupakan naluri yang paling kuat, yang menuntut penyaluran. Jika penyaluran tidak dapat memuaskan, maka orang akan mengalami kegoncangan dan kehilangan kontrol untuk mengendalikan nafsu berahinya, dan timbullah hubungan seks di luar ketentuan hukum, seperti, salah satunya homoseks (liwat).( Ramlan Yusuf Rangkuti, Jurnal asy-Syir'ah, Vol. 46, 2012)

Secara fitrah naluri pria dan wanita memiliki daya Tarik yang kuat. Inilah yang menjadi landasan pertama dalam ikatan diantara jenis insan untuk menuju kebahagiaan, yaitu adanya rasa tolong menolong dalam menjaga kehormatan dan menanggung kepenatan hidup. (Abbas Karahah, 1993: 105). Islam berpendapat bahwa kewajiban sang ayah dan para walinya terhadap putrinya adalah membina akhlaknya.

\section{Bahan dan Metode}

\section{Jenis Penelitian}

Penelitian ini merupakan penelitian terapan konsep dan peran serta dinas kesehatan serta ulama dan pemko pada penanggulangan HIV/AIDS homoseksual di kota Padang tata cara penanggulangan serta akibat diskriminasi LGBT terhadap perkembangan ekonomi dengan kombinasi pendekatan kualitatif serta kuantitatif dalam menghasilkan rekomendasi kebijakan bagi Pemerintah Kota Padang sebagai objek penelitian dalam bentuk model kebijakan penanggulangan penyakit HIV/AIDS dan homoseksual dan hubungannya dengan perekonomian bangsa. Selama ini tidak ada alat yang digunakan untuk mengevaluasi efisiensi dan efektifitas dari kebijakan tersebut.

\section{Tahapan Penyusunan Analisis kebijakan penanggulangan penyakit HIV/AIDS dan homoseksual}

Untuk menghasilkan kebijakan yang layak dan dapat diterapkan oleh Pemerintah Kota Padang, maka dilakukan beberapa tahapan kegiatan sebagai berikut :

\section{Tahap Pengumpulan Data}

Tahap pengumpulan data merupakan tahap pengambilan data berupa Dokumen Pelaksanaan kebijakan penanggulangan penyakit HIV/AIDS dan homoseksual bagi pemerintah kota dan dinas kesehatan yang ditentukan serta mendapatkan data-data yang diperlukan melalui wawancara kepada pihak terkait. 


\section{Tahap Penyetaraan Kegiatan}

Penyetaraan kegiatan dilakukan untuk menggolongkan berbagai kegiatan yang diperoleh dari tahap di atas ke dalam jenis atau kategori kegiatan yang memiliki pola dan kemiripan yang sama serta mempunyai bobot kerja yang sepadan.

\section{Teknik Pengumpulan Data}

Sumber data yang digunakan dalam analisis ini berasal dari data primer maupun data sekunder. Data primer diperoleh dari wawancara, focus group discussion dan kunjungan lapangan. Sedangkan data sekunder diperoleh dari berbagai sumber data yang berhubungan dengan kegiatan yang ada pada satuan kerja di lingkungan Pemerintah Kota Padang yang terangkum dalam Dokumen Pelaksanaan kebijakan penanggulangan penyakit HIV/AIDS dan homoseksual. Selanjutnya berdasarkan data yang diperoleh dari Satuan Kerja Perangkat kota akan diklasifikasikan berdasarkan kegiatan-kegiatan sejenis yang akan disusun Analisisnya.

\section{Teknik Analisis Data}

Teknik analisis yang digunakan dalam penyusunan ASB ini dilakukan dengan menggunakan metode kualitatif-rasionalistik. Metode ini didasarkan atas pendekatan secara menyeluruh dari suatu konsep umum yang diteliti pada objek tertentu, kemudian mendudukkan kembali hasil penelitian yang didapat pada konsep umumnya. Sedangkan untuk memaparkan analisis dalam penelitian ini digunakan metode deskriptif analisis dan metode sintesis preskriptif.

Metode deskriptif analisis dimaksudkan bahwa pengungkapan atau gambaran tentang keadaan yang faktual dan akurat tentang objek yang diamati yang dibahas secara analitis, bertitik tolak dari pemikiran, konsepsi, paradigma ataupun teori yang melandasi atau mempunyai hubungan dengan program terkait. Sedangkan metode sistesis preskriptif dimaksudkan untuk membangun kembali hasil analisis kritis yang telah dilakukan agar faktor-faktor yang relevan dan penting yang diperlukan dapat disintesis dalam konsep yang sistematis.

\section{PEMBAHASAN}

\section{EKONOMI DALAM ISLAM}

Ekonomi merupakan salah satu ilmu sosial yang mempelajari aktivitas manusia yang berhubungan dengan produksi, distribusi, dan konsumsi terhadap barang dan jasa. Istilah "ekonomi" sendiri berasal dari bahasa Yunani, yaitu oî́kos (oikos) yang berarti "keluarga, rumah tangga" dan vó Secara garis besar, ekonomi diartikan sebagai "aturan rumah tangga" atau "manajemen rumah tangga." Sementara yang dimaksud dengan ahli ekonomi atau ekonom adalah orang menggunakan konsep ekonomi, dan data dalam bekerja. https://id.wikipedia.org/wiki/Ekonomi).

Situasi sosial dan ekonomi global teridentifikasi adanya sekularisasi sistem dibuktikan dengan munculnya "hyper-consumption". Semua teori mengenai penanganan 
kemiskinan ketika tingkat pertumbuhan nasional naik ternyata gagal. (Faozan Amar:2016, 3)

Sistem ekonomi Islam peduli terhadap kemiskinan dan keadilan sosial-ekonomi, mempelajari ekonomi Islam merupakan srategi bagi para ahli ekonomi dan pembuat kebijakan. Sebagai makhluk Allah yang berkewajiban menegakkan hukum Islam di semua sisi kehidupan. Islam sendiri justru telah sempurna, termasuk dalam menyikapi masalah ekonomi dan merangkumnya dalam ilmu tauhid dan rukun Islam.

Dalam mengatur rumah tangga diperlukan harta, terbagi pada harta yang bergerak dan tidak bergerak. Contoh harta yang tidak bergerak adalah tanah, rumah, sedang harta yang bergerak seperti barang dagangan buah -buahan buku pakaian dan lain- lain. ( Nasrun Haroen:2000, 77). Sedang jika harta ini berlimpah akan lebih baik dikembangkan atau diinvestasikan demi kebaikan untuk orang banyak. Dan sebaik baik investasi adalah investasi akhirat.

Pada umumnya investasi dibedakan menjadi dua, yaitu investasi pada aset-aset finansial dan investasi pada aset-aset riil. Investasi pada aset finansial dapat dilakukan di pasar uang seperti di sertifikat deposito, surat berharga pasar uang, serta commercial paper, dan investasi di pasar modal yang meliputi saham, obligasi, opsi, waran, dan sebagainya. Investasi pada aset riil dapat berbentuk pendirian pabrik, perkebunan, pertambangan, dan pembelian aset produktif lainnya.

Dasar pijakan dari aktivitas ekonomi termasuk investasi adalah Al-Qur'an dan hadis Nabi saw. Selain itu, karena investasi merupakan bagian dari aktivitas ekonomi (muamalah māliyah), sehingga berlaku kaidah fikih, muamalah, yaitu "pada dasarnya semua bentuk muamalah termasuk di dalamnya aktivitas ekonomi adalah boleh dilakukan kecuali ada dalil yang mengharamkannya (QS: An-Nisa (4) : 29).

"Perumpamaan (nafkah yang dikeluarkan oleh) orang-orang yang menafkahkan hartanya di jalan Allah adalah serupa dengan sebutir benih yang menumbuhkan tujuh bulir, pada setiap bulir seratus biji. Allah melipat gandakan (ganjaran) bagi siapa yang Dia kehendaki dan Allah Maha Luas (karunia-Nya) lagi Maha mengetahui." (QS: Albaqarah: 268).

Ayat di atas menyampaikan betapa beruntungnya orang yang menafkahkan hartanya (menginvestasikan) di jalan Allah. Orang yang kaya secara financial (keuangan) kemudian menginfakkan hartanya untuk pemberdayaan masyarakat yang kurang mampu melalui usaha produktif, maka sesungguhnya dia sudah menolong ribuan, bahkan ratusan ribu orang miskin untuk berproduktif ke arah yang lebih baik

Menurut Halim (2005), investasi merupakan penempatan sejumlah dana pada saat ini dengan harapan akan dapat memberikan hasil atau keuntungan di masa yang akan datang. Pada umumnya investasi dibedakan menjadi dua, yaitu investasi pada asetaset finansial dan investasi pada aset-aset riil. Investasi pada aset finansial dapat dilakukan di pasar uang seperti di sertifikat deposito, surat berharga pasar uang, serta commercial paper, dan investasi di pasar modal yang meliputi saham, obligasi, opsi, waran, dan sebagainya. Investasi pada aset riil dapat berbentuk pendirian pabrik, 
perkebunan, pertambangan, dan pembelian aset produktif lainnya.

\section{INVESTASI DALAM PERSEPSI ISLAM}

Menurut Sula (2004), investasi keuangan menurut syariah dapat berkaitan dengan kegiatan perdagangan atau kegiatan usaha, dimana kegiatan usaha dapat berbentuk usaha yang berkaitan dengan suatu produk atau aset maupun usaha jasa. Namun investasi keuangan menurut syariah harus terkait secara langsung dengan suatu aset atau kegiatan usaha yang spesifik dan menghasilkan manfaat, karena hanya atas manfaat tersebut dapat dilakukan bagi hasil.

Kegiatan pembiayaan dan investasi keuangan menurut syariah pada prinsipnya adalah kegiatan yang dilakukan oleh pemilik harta (investor) terhadap pemilik usaha (emiten) untuk memberdayakan pemilik usaha dalam melakukan kegiatan usahanya di mana pemilik harta (investor) berharap untuk memperoleh manfaat tertentu. Karena itu, kegiatan pembiayaan dan investasi keuangan pada dasarnya sama dengan kegiatan usaha lainnya, yaitu memelihara prinsip kehalalan dan keadilan (p. 359-360).

Dalam Surat Lukman ayat 34 Allah SWT. menyebutkan dengan tegas bahwa tidak ada seorangpun di muka bumi ini yang dapat mengetahui apa yang akan dilakukan, diusahakan serta kejadian apa yang akan terjadi pada hari esok. Sehingga seluruh manusia diperintahkan untuk melakukan investasi sebagai bekal di dunia dan akhirat kelak.

Namun sesuai dengan perkembangan zaman selayaknya negara Indonesia yang masih dianggap kurang dalam kemajuan ekonomi PBB berinisiatif memberikan bantuan dana demi membantu para kaum LGBT yang dilihat sebelah mata oleh masyarakat dan membantu mereka agar berkembang ditengah masyarakat dan diterima sebagai layaknya masyarakat lain dan menjunjung tinggi hak azazi manusia

UNDP pun merinci beberapa tujuan dari proyek kemitraan regional Indonesia. Salah satunya adalah mendukung kaum LGBTI untuk mengetahui hak-hak mereka dan mendapatkan akses ke pengadilan guna melaporkan pelanggaran-pelanggaran HAM. Hasil-hasil yang ingin dicapai dari proyek ini, salah satunya adalah meningkatnya kemampuan organisasi-organisasi LGBTI untuk secara efektif memobilisasi, menyokong dan berkontribusi dalam dialog-dialog kebijakan dan aktivitas pemberdayaan komunitas.

Sebagian pendapat menyatakan adanya diskriminasi kaum LGBT mengakibatkan para kaum minoritas ini tersudut sebagian penggerak ham mengusulkan adanya undang undang anti diskriminasi terhadap LGBT dan menerima keberadaan mereka di tengah masyarakat. Hal ini dianggap penyebab menurunnya tingkat kepercayaan para investor dalam dan luar negeri untuk berinvestasi di Indonesia, padahal investasi yang tidak sesuai dengan syariat Islam akan menghancurkan ekonomi itu sendiri karena hanya karena banyak mengandung unsur riba penipuan dan mengundi nasib memikirkan keuntungan pribadi, sementara dalam Islam lebih memikirkan keuntungan bersama terutama membantu orang yang lemah dan berusaha sebanyak mungkin berinvestasi untuk akhirat. Justru jika kaum LGBT ini direhabilitasi dan segera bertobat kemungkinan ekonomi suatu negara akan lebih baik karena mereka sudah hidup tenang 
dengan rahmat Allah dan diterima seluruh lapisan masyarakat.

\section{DISKRIMINASI LGBT DI INDONESIA}

Hak asasi manusia adalah hak yang melekat pada semua manusia, apa pun kebangsaan kita, tempat tinggal, jenis kelamin, asal kebangsaan atau etnis, warna kulit, agama, bahasa, atau status lainnya. Kita semua sama berhak atas hak asasi manusia kita tanpa diskriminasi. Hak-hak ini semuanya saling terkait, saling bergantung dan tak terpisahkan (UN High Commission for Human Rights, 2018).

Di Indonesia, instrumen hukum yang berlaku serta berperspektif HAM tidaklah sedikit. Sebut saja UUD NRI 1945, UU HAM No. 39/1999, Ketenagakerjaan No. 13/2003, UDHR 1948 dan lain sebagainya. Beberapa peraturan perundang-undangan yang berlaku di Indonesia, baik secara eksplisit atau implisit tetap memberikan jaminan akan perlindungan hak-hak asasi manusia.

Indonesia merupakan negara yang mengakui HAM sebagai sesuatu yang eksis dan harus dihormati dan dilindungi. Bab XA UUD NRI 1945 merupakan bab yang secara khusus mengatur tentang HAM di Indonesia secara umum. UUD NRI 1945 secara hierarki merupakan peraturan perundang-undangan tertinggi yang menjadi acuan peraturan perundang-undangan lain di bawahnya, sehingga tidak akan ada peraturan di Indonesia yang tidak mengakui HAM. Selain itu, Indonesia juga mengakui UDHR 1948 yang menjadi instrumen HAM internasional yang diakui oleh bangsa-bangsa di dunia.

Hal yang menjadi fokus permasalahan adalah bagaimana perlakuan dan sikap bangsa Indonesia, terhadap perilaku seksual menyimpang kaum LGBT yang melakukan perbuatan tersebut dilandasi dengan asas kebebasan HAM. Sebagaimana telah dijelaskan sebelumnya bahwa Indonesia merupakan negara yang masih kental dengan ajaran agama, moral, dan etika yang telah berkembang dan mengakar di seluruh lapisan masyarakatnya. Perilaku "menyimpang" kaum LGBT tentu tidak bisa diterima begitu saja, karena selalu ada alasan-alasan mendasar dari masyarakat untuk menolak pelaku dan perilaku seksual menyimpang, baik itu didasari atas ajaran agama maupun budaya.

Ham dalam Islam telah dijelaskan dalam sumber ajaran Islam yaitu al-Qur'an dan Hadis juga terdapat dalam pelaksanaan kehidupan manusia, terbukti Islam mengakui HAM yaitu tidak ada paksaan dalam beragama, seperti menghargai kesuian nyawa manusia untuk mendapatkan hak hidup, seperti larangan membunuh dan bunuh diri da nada ketentuan qisas.Melindungi kaum wanita dan memiliki hak yang sama tidak membedakan suku kecuali bertkwa.

Meskipun tidak semua masyarakat menolak, sikap "diskriminasi" yang dirasakan oleh kaum LGBT dianggap sebagai pelanggaran HAM. Karena kaum LGBT hidup hampir di setiap bagian belahan dunia, mereka adalah bagian dari anggota masyarakat, etnis, dan agama tertentu. Mereka juga adalah manusia yang harus dihormati haknya, akan tetapi di beberapa negara (termasuk Indonesia) mereka mengalami diskriminasi yang disebabkan oleh identitas dan orientasi seksual (Badgett, Nezhad, Waaldijk, dan an memandang derajat manusia itu sama tidak membedakan warna kuli keuali bertaqwa. 
Komisaris Tinggi Perserikatan Bangsa-Bangsa untuk Hak Asasi Manusia melaporkan bahwa: "hampir di semua wilayah, terdapat orang yang mengalami kekerasan dan diskriminasi karena orientasi seksual atau identitas gender mereka... pelanggaranpelanggaran HAM yang Fenomena ini membuktikan dengan jelas bahwa masyarakat Indonesia sulit memberikan ruang untuk pemenuhan hak-hak kelompok LGBT ini sebagai bagian dari warga negara Indonesia. Berbagai pelanggaran HAM mereka dapati, mulai dari kekerasan verbal seperti cibiran, hingga kekerasan fisik seperti disiram air, ditelanjangi, bahkan dibunuh masih terjadi, apalagi mereka yang dari kalangan transgender atau waria.

Juru bicara Komisi Hak Asasi Manusia PBB di Jenewa, Swiss, Rupert Colville, menyatakan hukum di Indonesia tidak adil karena para pelaku LGBT yang ditangkap tidak terlibat tindak kejahatan apapun. Menurut Colville, kaum LGBT di Indonesia ditangkap hanya karena orientasi seksualnya dan dijerat dengan undang-undang antipornografi yang selalu digunakan untuk menjerat penyuka sesama jenis.

Colville menegaskan memperlakukan pelaku LGBT seperti penjahat hanya karena orientasi seksualnya atau gender melanggar hukum internasional. Menurutnya, itu sama saja merendahkan martabat mereka sebagai manusia, pemaksaan menjalani pemeriksaan medis juga merupakan bentuk perlakuan kejam dan tidak manusiawi, apalagi mereka selalu dituduh terlibat pelacuran, yang dalam kenyataannya tidak terbukti. Di dalam Islam sangat memperhatikan HAM terbukti dengan tidak memaksa orang memeluk Islam, dan melarang membunuh orang tanpa hak.

\section{SEKSUALITAS DALAM HUKUM ISLAM DAN PERUNDANG-UNDANGAN DI INDONESIA}

\section{Seksualitas dalam Hukum Islam}

Pandangan Islam terhadap seksual bertitik tolak dari pengetahuan tentang fitrah manusia dan usaha pemenuhan seksualnya agar setiap individu dalam masyarakat tidak melampaui batas-batas fitrahnya. Ia harus berjalan dengan cara normal seperti yang telah digariskan Islam. Firman Allah SWT dalam Al Qur'an QS:54:21 prosesnya dengan jalan pernikahan.

"Dan di antara tanda-tanda kekuasaan-Nya ialah Dia menciptakan untukmu istri-istri dari jenismu sendiri, supaya kamu cenderung dan merasa tentram kepadanya, dan dijadikan-Nya di antaramu rasa kasih dan sayang. Sesungguhnya pada yang demikian itu benar-benar terdapat tanda-tanda bagi kaum yang berfikir" (QS. Ar-Rhuum: 21).

Islam menghendaki hubungan seks yang normal melalui pernikahan dengan niat mencurahkan semua waktunya untuk ibadah kepada Allah SWT. Untuk mengatasi kerusakan jiwa dan mengarahkan agar berahlak mulia, Islam menghendaki fitrah manusia berjalan sesuai dengan kehendak Yang Maha Kuasa. Hanya agama Islam yang tidak menyetujui pandangan bahwa mengekang naluriah seksual yang alami tidak dapat dikaitkan dengan tingginya derajat dan nilai kemuliaan seseorang. Pandangan tersebut bertentangan dengan seluruh konsep moral dan spiritual yang ditanamkan oleh Islam. Naluri alamiah, bahkan kecakapan mental atau kegagalan fisik sekalipun, adalah karunia Allah SWT. 
Berangkat dari tugas dan kewajiban Muslim sebagai hamba Allah berbakti mengabdi, dan menyembah kepada-Nya, maka segala bentuk kehidupan secara utuh dan total bagi seorang muslim ialah demi dan untuk pengabdian itu sendiri. Seks bagian kehidupan manusia seks bisa sebuah kenikmatan yang membahagiakan juga bisa sebuah awal kehancuran dan kesengsaraan (Lukman Saksono, 2019:315).

Ada dua fakta fundamental yang menentukan strategi seksual masyarakat Muslim dalam dekade mendatang. Pertama ketergantungan mereka terhadap ekonomi yang membuat kaum borjuis negara tersebut tidak dapat mengerjakan untuk sekelompok penduduk dengan jumlah kelahiran yang tertinggi di dunia. Kedua bahwa budaya muslim telah tersusun dalam kebutaan ideologi kepada dimensi ekonomi atas wanita, yang secara biasa dapat dimengerti dapat dikhayalkan dan didefinisikan sebagai sasaran khusus seksual.(Lukman Saksono, 2019:32).

Nafsu merupakan bagian dari makhluk Allah. Dengan berbekal nafsu pula manusia dapat menjalankan kehidupannya secara wajar sebagai makhluk yang hidup di alam dunia. Berbagai kebutuhan penting manusia, seperti makan, minum, tidur, menikah, dan lain sebagainya, melibatkan nafsu di dalamnya. Secara alamiah nafsu bukanlah hal yang mutlak buruk. Namun demikian, nafsu memiliki kecederungan-kecenderungan untuk menyimpang. Kerena itu, dalam Islam terkandung anjuran kuat untuk mengendalikan nafsu. Memang manusia tidak diperintahkan untuk memusnahkannya, namun nafsu harus memegang kuasa penuh agar selamat dari jebakan dan godaan-godaannya yang menjerumuskan.

Pilihannya hanya dua, menguasai nafsu atau justru dikuasai oleh nafsu. Dua pilihan ini pula yang menentukan apakah akan memperoleh kebahagiaan hakiki atau tidak. Imam Abu Hamid al-Ghazali pernah mengatakan dalam kitab Ihyâ' 'Ûlûmiddîn: "Kebahagiaan adalah ketika seseorang mampu menguasai nafsunya. Kesengsaraan adalah saat seseorang dikuiasai nafsunya."( Ihya ulumuddin, terj. 2009:37)

Tinjauan Islam tentang seksual dalam penulisan ini ialah perilaku manusia secara benar yang diridhai Allah SWT sesuai dengan fitrahnya, hidup harmonis dan dapat memenuhi tuntutan kehidupan secara normal tanpa mengabaikan kebutuhan lainnya. Adapun hubungan seksual terbagi atas dua jenis hubungan, yaitu:

\section{Hubungan seksual yang dihalalkan.}

Pada prinsipnya dalam Islam ada dua tujuan pokok dari lembaga perkawinan. Pertama, mendapatkan ketentraman hati, terhindar dari kegelisahan, dan kebimbangan yang tidak berujung pangkal. Kedua, melahirkan keturunan anak yang saleh/salihah, Allah SWT berfirman :

"Hai sekalian manusia, bertakwalah kepada Tuhan-mu yang telah menciptakan kamu dari diri yang satu, dan daripadanya Allah menciptakan istrinya; dan dari pada keduanya Allah memperkembang biakkan laki-laki dan perempuan yang banyak. Dan bertakwalah kepada Allah yang dengan (mempergunakan) nama-Nya kamu saling meminta satu sama lain dan (peliharalah) hubungan silaturrahim. Sesungguhnya Allah selalu menjaga dan mengawasi kami” (QS. An Nisaa: 1).

"Allah menjadikan bagi kamu istri-istri dari jenis kamu sendiri dan menjadikan 
bagimu dari istri-istri kamu itu, anak-anak dan cucucucu, dan memberiku rezki dari yang baik-baik. Maka mengapakah mereka beriman kepada yang batil dan mengingkari nikmat Allah?" (QS. An-Nahl: 72).

Allah SWT memberikan kebebasan seksual sebebas-bebasnya sesuai dengan firman-Nya :

"Istri-istrimu adalah (seperti) tanah tempat kamu bercocok tanam, maka datangilah tanah tempat bercocok-tanammu itu bagaimana saja kamu kehendaki. Dan kerjakanlah (amal yang baik) untuk dirimu, dan bertakwalah kepada Allah dan ketahuilah bahwa kamu kelak akan menemui-Nya. Dan berilah kabar gembira orang-orang yang beriman" (QS. Al Baqarah: 223).

Dalil di atas menunjukkan, bahwa seksual adalah fitrah manusia yang harus disalurkan melalui nikah. Hal ini dimaksudkan untuk menciptakan keluarga sakinah, mawaddah dan warahmah. Nikah (kawin) menurut arti istilah ialah hubungan seksual tetapi arti majazi (methaporic) atau arti hukum ialah akad (perjanjian) nikah yang menjadikan halal hubungan seksual sebagai suami istri antara seorang pria dengan seorang wanita.

Menurut Imam Syafi'i, pengertian nikah adalah suatu akad yang dengannya menjadi halal hubungan seksual antara pria dengan wanita sedangkan menurut arti majazih artinya hubungan seksual. Mahmud Yunus mengartikan nikah sebagai hubungan seksual. Sedangkan Hazairin mengatakan bahwa inti perkawinan itu adalah hubungan seksual, menurut beliau tidak ada nikah (perkawinan) apabila tidak ada hubungan seksual.

Dari berbagai pengertian di atas, nikah lebih berkonotasi pada hubungan seksual antara laki-laki dan perempuan. Oleh karena itu dapat disimpulkan bahwa hubungan seks yang halal dalam perspektif Islam adalah hubungan seks yang dilakukan oleh laki-laki dengan perempuan melalui pernikahan.

\section{Hubungan seksual yang terlarang}

Hubungan seksual yang terlarang maksudnya ialah hubungan suami istri pada waktu-waktu tertentu seperti sedang haid, nifas dan melakukan hubungan seksual kepada wanita lain selain istrinya yang sah. Berikut ini dalil hubungan seks yang terlarang:

1) Hubungan seksual ketika istri dalam keadaan haid atau nifas, Allah SWT berfirman :

"Mereka bertanya kepadamu tentang haid. Katakanlah:

'haid itu adalah kotoran'. Oleh sebab itu hendaklah kau menjauhkan diri dari wanita di waktu haid dan janganlah kamu mendekati mereka, sebelum mereka suci. Apabila mereka telah suci, maka campurilah mereka itu di tempat yang diperintahkan Allah kepadamu. Sesungguhnya Allah menyukai orang-orang yang taubat dan menyukai orang-orang yang mensucikan diri" (QS. Al Baqarah: 222).

2) Homoseksual 
Menurut Islam, homoseksual disebut liwath atau "amal qaumi luthin". istilah tersebut timbul karena perbuatan seperti itu pertama kali dilakukan oleh umat Nabi Luth yang hidup sezaman dengan Nabi Luth (Yatimin, 2003: 33). Hal ini dijelaskan oleh Allah SWT dengan firman-Nya:

"Dan (kami juga telah mengutus) Luth (kepada kaumnya). (Ingatlah) tatkala dia berkata kepada kaumnya: 'Mengapa kamu mengerjakan perbuatan faahisyah itu, yang belum pernah dikerjakan oleh seorangpun (di dunia ini) sebelummu?. Sesungguhnya kamu mendatangi laki-laki untuk melepas nafsumu (kepada mereka), bukan kepada wanita, malah kamu ini adalah kaum yang melampaui batas" (QS. AnNaml: 54-53) Hubungan seksual dengan cara zina

Hukum Islam memandang setiap hubungan kelamin diluar nikah sebagai zina dan mengancamnya dengan hukuman, baik pelaku sudah kawin atau belum kawin, dilakukan suka sama suka atau tidak (Ahmad Wardi Muslich, 2005: 3). Dalam Islam, zina dikategorikan sebagai perbuatan keji dan merusak keturunan. Zina ada dua macam, yaitu zina gairu muhsan ialah zina yang dilakukan oleh laki-laki atau perempuan merdeka (bukan hamba sahaya) yang belum menikah atau belum berkeluarga. Hukuman bagi pelaku zina ghairu muhsan adalah didera (cambuk) sebanyak 100 kali dan dibuang ke luar daerah selama satu tahun bagi mereka yang merdeka, dan separuhnya bagi hamba sahaya.

Zina muhsan, yaitu zina yang dilakukan oleh laki-laki atau perempuan yang sudah pernah menikah atau dalam keadaan masih mempunyai ikatan pernikahan dan merdeka. Hukuman terhadap zina muhsan adalah rajam. Allah SWT berfirman dalam Al Qur'an, surah Al-Israa' ayat 32: "Dan janganlah kamu mendekati zina; sesungguhnya zina itu adalah suatu perbuatan yang keji. Dan suatu jalan yang buruk".

4) Onani dan Masturbasi

Istimna' yang dikenal dalam bahasa indonesia dengan sebutan onani atau masturbasi adalah merangsang anggota seksual baik yang dilakukan oleh laki-laki atau perempuan dengan tujuan menikmati sensasi rangsangan atau mengeluarkan mani.( Abu Taimiyah, Nazhatul albab fi istimna'ir rijal wan nisa', hal: 4) . ulama yang mengharamkan secara mutlak adalah dari kalangan, Malikiyah, dan Zaidiyin, sebagaimana yang dijelaskan oleh Sayyid Sabiq di dalam kitabnya.( Sayid Sabiq, Fiqhus Sunnah Sayid Sabiq, Al-fath lil i'lam Al-'arobi, juz 2, hal:393)

Istimna' yaitu onani atau masturbasi jika sampai keluarnya mani, maka wajib bagi pelakunya mandi besar, dan dia sama seperti orang yang junub. Rasulullah Shallallahu 'alaihi wa sallam bersabda, “ wajibnya mandi besar itu karena air (air mani)

\section{SEKSUALITAS DALAM PERUNDANG-UNDANGAN DI INDONESIA}

Negara Indonesia adalah Negara hukum yang berdasarkan Pancasila dengan menjunjung tinggi nilai-nilai moral, etika, akhlak mulia dan kepribadian luhur bangsa, beriman dan bertakwa kepada Tuhan Yang Maha Esa, menghormati kebinekaan dalam kehidupan bermasyarakat berbangsa dan bernegara, serta melindungi, harkat dan martabat setiap warga negara. 
Pada Pasal 3 Undang-Undang bertujuan a) mewujudkan dan memelihara tatanan kehidupan masyarakat yang beretika, berkepribadian luhur menjunjung tinggi nilai nilai Ketuhanan Yang Maha Esa serta menghormati harkat dan martabat kemanusiaan; b) menghormati, melindungi dan melestarikan nilai seni dan budaya, adat istiadat dan ritual keagamaan masyarakat Indonesia yang majemuk. (Undang-Undang R.I.Tentang Pornografi dan Informasi dan Transaksi Elektronik Nomor 11 Tahun 2008, 2011:3).

Kontruksi seksualitas dalam perundang-undangan di Indonesia tertuang dan diatur dalam UUD 1945, Burgelijik Wetbook/KUHPerdata, KUHP, UU No. 1 Tahun 1974 tentang Perkawinan, Kompilasi Hukum Islam (KHI) bagi umat Islam di Indonesia, dan undang-undang lainnya. Di dalam UUD 1945 pasal 28 B UUD 1945 disebutkan bahwa:

"setiap orang berhak membentuk keluarga dan melanjutkan keturunan melalui perkawinan yang sah". Dalam pasal 2 UU No. 1 Tahun 1974 disebutkan bahwa perkawinan yang sah apabila dilakukan menurut hukum masing- masing agama dan kepercayaannya itu.(Undang-Undang Nomor 1 Tahun 1974 Tentang Perkawinan dan Kompilasi Hukum Islam:35).

Di Indonesia sendiri, perkawinan homoseksual tidak diakui oleh hukum Indonesia. Berdasarkan Pasal 1 Undang-Undang Nomor 1 Tahun 1974 tentang Perkawinan ("UU Perkawinan"), perkawinan adalah ikatan lahir batin antara seorang pria dengan seorang wanita sebagai suami isteri.

Pasal 1 UU Perkawinan:

"Perkawinan ialah ikatan lahir bathin antara seorang pria dengan seorang wanita sebagai suami isteri dengan tujuan membentuk keluarga (rumah tangga) yang bahagia dan kekal berdasarkan Ketuhanan Yang Maha esa."(UndangUndang Nomor 1 Tahun 1974 Tentang Perkawinan dan Kompilasi Hukum Islam:3)

Legalitas kaum homoseksual memang tidak ada. Ada wacana larangan perbuatan homoseksual untuk dimasukan dalam RUU KUHP. Selama ini yang dilarang KUHP hanya homoseksual yang dilakukan terhadap anak-anak di bawah umur. Pasal 292 Kitab Undang-Undang Hukum Pidana (KUHP) tidak secara tegas melarang homoseksual yang dilakukan antar orang dewasa, perlu penegasan terhadap larangan homoseksual, dan zina.

Pasal 292 KUHP yang berbunyi:

“Orang yang cukup umur, yang melakukan perbuatan cabul dengan orang lain sama kelamin, yang diketahui atau sepatutnya harus diduga, bahwa belum cukup umur, diancam dengan pidana penjara paling lama lima tahun"

Dari Pasal 292 KUHP jerat pidana bagi pelaku homoseksualitas memang ada, yakni apabila dilakukan oleh orang dewasa dengan anak di bawah umur yang berjenis kelamin sama. Namun, memiliki sifat penyuka atau ketertarikan dengan sesama jenis tidak dipidana, tetapi apabila diikuti dengan perbuatan cabul, maka pelakunya dapat dipidana 
Hasil wawancara dengan para pengidap LGBT di kota Padang, menunjukkan belum adanya kesadarn para kaum gay untuk kembali ke jalan yang benar, sementara ulama mensarankan agar mereka segera bertobat dan menikah.

\section{KESIMPULAN}

Pendapat ulama menyarankan untuk segera bertobat dan mensyukuri nikmat fitrah kesempurnaan ciptaan manusia dengan berpasang pasangan segera menikah.

1. Segera merevisi kembali Rancangan Undang Undang pasal 292 tentang hukum pidana bagi pengidap homoseksual dihukum lima tahun dan berlaku untuk penderita homoseksual orang dewasa maupun anak dibawah umur begitu juga para penyuka sesama jenis dihukum pidana penjara maksimal satu tahun agar menimbulkan efek jera.

2. Menurut hukum Islam disamakan dengan pidana zina berlaku hukum cambuk bagi penderita lajang dan rajam bagi yang telah berkeluarga.

3. Menutup rapat bantuan dana dari pihak mananpun untuk mendorong kemajuan perkembangan LGBT, walau berdalih untuk menanam investasi karena LGBT bertentangan dengan ajaran Islam, serta melakukan pembinaan mental pada kaum LGBT untuk segera bertobat.

\section{Saran}

1. Berharap kepada pemerintah kota Padang menerapkan rancangan UndangUndang Pasal 292 tentang hukum pidana pengidap homoseksual baik dewasa maupun anak-anak dipidana selama lima tahun atau maksimal sepuluh tahun.

\section{Daftar Pustaka}

Abbas Karahah, 1993. Berbicara Dengan Wanita, Jakarta, Gema Insani Pres

Ahmad Wardi Muslich, 2005, Hukum Pidana Islam, Sinar Grafika, Jakarta.

Alqur'an Dan Terjemahannya, Kementerian Agama, 2005

Depkes RI. (1983), Pedoman dan Penggolongan Diagnosis Jiwa (PPDGJ) II, Jakarta Depkes RI.

Hafid Cangara, Pengantar Ilmu Komunikasi, Jakarta Rajagrafindo Persada.

Kartono, K. (1989) Psikologi Abnoormal dan Abnormalitas seksual. Bandung:

Mandar Maju.

Lukman Saksono, 2019, Seks ddengan wanita, Jakarta: Muslim, Jakarta: Grafikatama jaya.

Undang-Undang RI tentang Pornografi dan ITE, 2011, Jogjakarta: Pustaka

Mahardhika

Undang-Undang NO.1 Tahun 1974, 2015, Tentang Perkawinan dan KHI, Surabaya: 
ISSN 2657-1080

ISSN 1858-3687

Akuntansi dan Manajemen Vol.15, No.1, 2020

Sinarsindo Utama.

Sayid Sabiq, Fiqhus Sunnah Sayid Sabiq, Al-fath lil i'lam Al-'arobi, juz 2

Suprapto tommy. 2009. Pengantar teori dan manajemen komunikasi. Yogyakarta : Media pressindo.

Yus Darusman, Wiwin Herwina, 2016, Luka liku kehidupan waria suatu kajian pencemaran lingkungan sosial dan penanggulangannya melalui pendidikan luar sekolah, Bandung: Pelangi Press

Ramlan Yusuf Rangkuti, Jurnal asy-Syir'ah, Vol. 46, 2012

Yulfira Media, 2016 . Laporan Penelitian

Wawancara, Fulan 30 September 2019 